\title{
KONZERVATORSKO-RESTAURATORSKI RADOVI NA PORTRETU MARIJE TEREZIJE IZ GRADSKOG MUZEJA VARAŽDIN
}

Članak se bavi konzervatorsko-restauratorskim radovima izvedenim na portretu Marije Terezije iz prve polovine 18. stoljeća. Portret je pripisan radionici slikara Martina van Meytensa, iako njegov potpis prilikom istraživačkih radova u predmetnoj restauraciji nije pronađen. Tehnika slike je ulje na platnu, a portret prikazuje Mariju Tereziju koja je kao ugarsko-hrvatska i češka kraljica vladala u doba Habsburške Monarhije od 1740. do 1780. godine, te je u svojoj vladavini uvela brojne reforme $u$ vanjskoj $i$ unutarnjoj politici. Portret je naveden kao najzanimljiviji i umjetnički najvrjedniji portret u fundusu Gradskog muzeja Varaždina. Potječe iz razmjerno ranog razdoblja vladavine Marije Terezije. Osim po svojoj iznimnoj umjetničkoj vrijednosti, slika je specifična i po svojim ranijim restauratorskim intervencijama izvedenim 1857. i 1993. godine. Tadašnji zahvati na slici izazvali su mnoge polemike u pronalaženju optimalnih rješenja za predmetnu restauraciju i konzervaciju koja je dovršena 2014. godine u Hrvatskom restauratorskom zavodu.

\section{UVOD}

U višegodišnjoj i vrlo uspješnoj suradnji Hrvatskog restauratorskog zavoda i Gradskog muzeja Varaždin, restauriran je i portret Marije Terezije iz izrazito lijepe 
i bogate kolekcije slika koja se može razgledati u prostorijama već spomenutog muzeja. Slika je datirana u katalogu Varaždin pod krunom Habsburgovaca, oko 1745. godine, te nam o iznimnosti tog portreta za grad Varaždin, ukazuju i činjenice da godine 1750. uvrštenjem u gradski statut, Marija Terezija uvodi službeno utemeljenje varaždinske građanske garde, a 1763. godine Varaždincima šalje povelju s pečatom i grbom. Godine 1767.osnovala je i Hrvatsko kraljevsko vijeće sa sjedištem u Varaždinu ${ }^{1}$. Slika potječe iz ranog razdoblja njezine vladavine, a prikazuje je cijelim stasom u slavljeničkoj brokatnoj odori. Stoji kraj bogato izrezbarenog stola na kojem se nalazi svečano ukrašen jastuk s dvije položene krune austrijskih nadvojvoda. Visina slike je $203 \mathrm{~cm}$, a širina $140 \mathrm{~cm}$. Slika je pripisana radionici Martina van Meytensa (1695.- 1770.). On je bio najznačajniji dvorski slikar Marije Terezije imenovan 1732. godine. Kao dvorski slikar dinastije Habsburg naslikao je brojne pojedinačne i skupne portrete članova carske obitelji i visokog plemstva, te spada u značajnije austrijske barokne slikare.

Djelovao je u Nizozemskoj, Engleskoj, Francuskoj i Italiji. Od 1730-tih u Beču postaje vrlo cijenjen portretist velikaških obitelji. Meytens je bio jedan od značajnijih autora reprezentativnih baroknih dvorskih portreta, a svoje je znanje prenio i na niz mlađih slikara među kojima su i autori slika iz fundusa hrvatskih muzeja i galerija: A. J. Braun, J. D. Donat, J. M. Millitz, J. G. Weickert i dr. ${ }^{2}$

Na platnu uspravnog pravokutnog formata prikazana je cijela figura Marije Terezije u stojećem položaju, s carskim žezlom u lijevoj ruci kojom se naslanja na jastuk s dvama krunama. Raskošna odjeća od bijelog brokata vezenog zlatom podstavljena je svijetlo plavom tkaninom i ukrašena čipkom, a s desnog ramena $\mathrm{i}$ ispod ruke joj je prebačen plašt od zlatnog brokata. Tamna draperija u pozadini u kontrastu je sa svijetlim caričinim likom.

U donjem desnom kutu slike, u sloju preslika, vidljiva je teško čitljiva signatura koja se najbolje razaznaje uz pomoć makrofotografije, a glasi Mayerwieser renoviert 1857, dok se u dostavljenoj dokumentaciji iz 1993. tumači da se na slici nalazi naziv Meytensen pinxit 1857. kojeg je Mayerwieser potpisao prilikom obnavljanja slike 1857. godine. Martin van Meytens živio je do 1770. godine. Taj nam podatak potvrđuje da je naziv Mayerwieser renoviert 1857. nastao prilikom prve restauracije na slici u izvedbi austrijskog slikara Mayerwiesera koji u Hrvatskoj djeluje od 1856. godine. Prilikom istraživačkih radova u predmetnoj restauraciji, potpis Martina van Meytensa nije pronađen. Kao najljepšu sliku cijele

1 Varaždin pod krunom Habsburgovaca, katalog izložbe, autorice koncepcije Mirjana Dučakijević i Spomenka Težak, Gradski muzej Varaždin, Varaždin, 2015., 51.,104.-105., 140.

2 Marijana SCHNEIDER, Portreti 16 - 18. stoljeća, Povijesni muzej Hrvatske, Zagreb, $1982 ., 27$. 
zbirke Krešimir Filić navodi portret Marije Terezije gdje je prikazana kao vladarica u raskošnom odijelu s diademom i kraljevskim žezlom u ruci. On također navodi da je sliku najvjerojatnije naručila gradska općina oko 1750. godine, i da se od tog doba nalazila u gradskoj vijećničkoj dvorani, kasnije u sobi načelnika, da bi na kraju završila na svojem sadašnjem mjestu. U njegovom se tekstu nalazi i podatak da je Ferdinand (?) Mayerwieser „popravio i dotjerao“ sliku 1857. godine, te da je upriličio mnoge društvene scene na pločama streljačkog društva. Spomenute se Mayerwieserove slike na pločama također mogu naći u prostorijama Gradskog muzeja Varaždin. ${ }^{3}$ U katalogu portreta 1800 - 1870., autorice Marijane Schneider, nailazimo na podatak da je Mayerwieser slikar nepoznatog porijekla i biografije koji je djelovao u Hrvatskoj sredinom 19. stoljeća, te da je restaurirao veliki portret Marije Terezije u Varaždinu 1856. godine. ${ }^{4}$ Iako na slici nailazimo na naziv Mayerwieser, Krešimir Filić ga navodi kao slikara punim imenom i prezimenom pod nazivom Ferdinand Mayerwieser.

\section{OPIS STANJA SLIKE NAKON PREUZIMANJA U KOLOVOZU 2013. GODINE}

Slika je preuzeta ovješena i valovita, bez unutarnjeg i ukrasnog okvira. Nosilac slike je laneno platno, rijetkog tkanja i grublje strukture. Sastavljeno je iz dva dijela, međusobno spojenih okomito šivanjem. Platno je bilo deformirano i istanjeno po rubovima. U prethodnoj intervenciji na rubove su dodane lanene trake širine oko $5 \mathrm{~cm}$. Mehanička oštećenja bila su vidljiva po cijelom formatu: perforacija pored desne ruke oko $2 \mathrm{~cm}$, na lijevoj ruci horizontalna poderotina veličine oko $12 \mathrm{~cm}$, te u gornjem lijevom kutu horizontalna poderotina oko 13 $\mathrm{cm}$. Na rubovima su perforacije nastale oksidacijom čavala. Perforacije platna su u restauraciji iz 1993. godine bile sanirane neiskrojenim četvrtastim intarzijama od lanenog platna umetnutim s poleđine neadekvatnim, tvrdokornim ljepilom, a s lica je voštana masa mjestimice bila nanesena i preko slikanog sloja, izvan zone oštećenja. Neke perforacije i oštećenja bile su zakitane tvrdokornim kitom nepoznatog sastava. Po cijelom su formatu, zbog oslabljenog veziva mjestimice bili otpali dijelovi podloge i boje, a to je naročito bilo izraženo po rubovima. Cijelom površinom, slika je bila puna krakelira, a zbog popuštanja veziva u podlozi i boji, neke su krakelire poprimile zdjeličasti oblik. Na licu slike nazirao se i otisak podokvira, a slikani sloj bio je prekriven slojem nečistoće i požutjelog laka koji je na pastoznijim nanosima i u „čašicama“ ispucale boje, bio dosta tamniji. Veći dio

3 Krešimir FILIĆ, Varaždinski muzej, u spomen 20-godišnjice postojanja „Varaždinskog muzealnog društva", Varaždin, 1943. 44., 52.-53.

4 Marijana SCHNEIDER, Portreti 1800 - 1870., Povijesni muzej Hrvatske, Zagreb, 1973. 28.-29. 
završnog sloja laka bio je vidljiv u obliku tamnih kapljica, što je ukazivalo na lakiranje slike bez temeljitijeg prethodnog uklanjanja površinskih naslaga nečistoće, a mjestimice se nazirao i tanji sloj originalnog laka. Mnogobrojni alterirani retuši bili su izraženiji na licu i rukama Marije Terezije. Na slici su nađeni ostaci preslika, naročito u gornjem lijevom kutu, te ostaci zelene boje između zlatnih brokata haljine. $U$ donjem desnom kutu slike, u sloju preslika, vidljiva je pomalo nečitka signatura Mayerwieser renoviert 1857. iako se prema dostavljenoj dokumentaciji iz 1993. godine navodi da na slici postoji natpis Meytensen pinxit 1857.

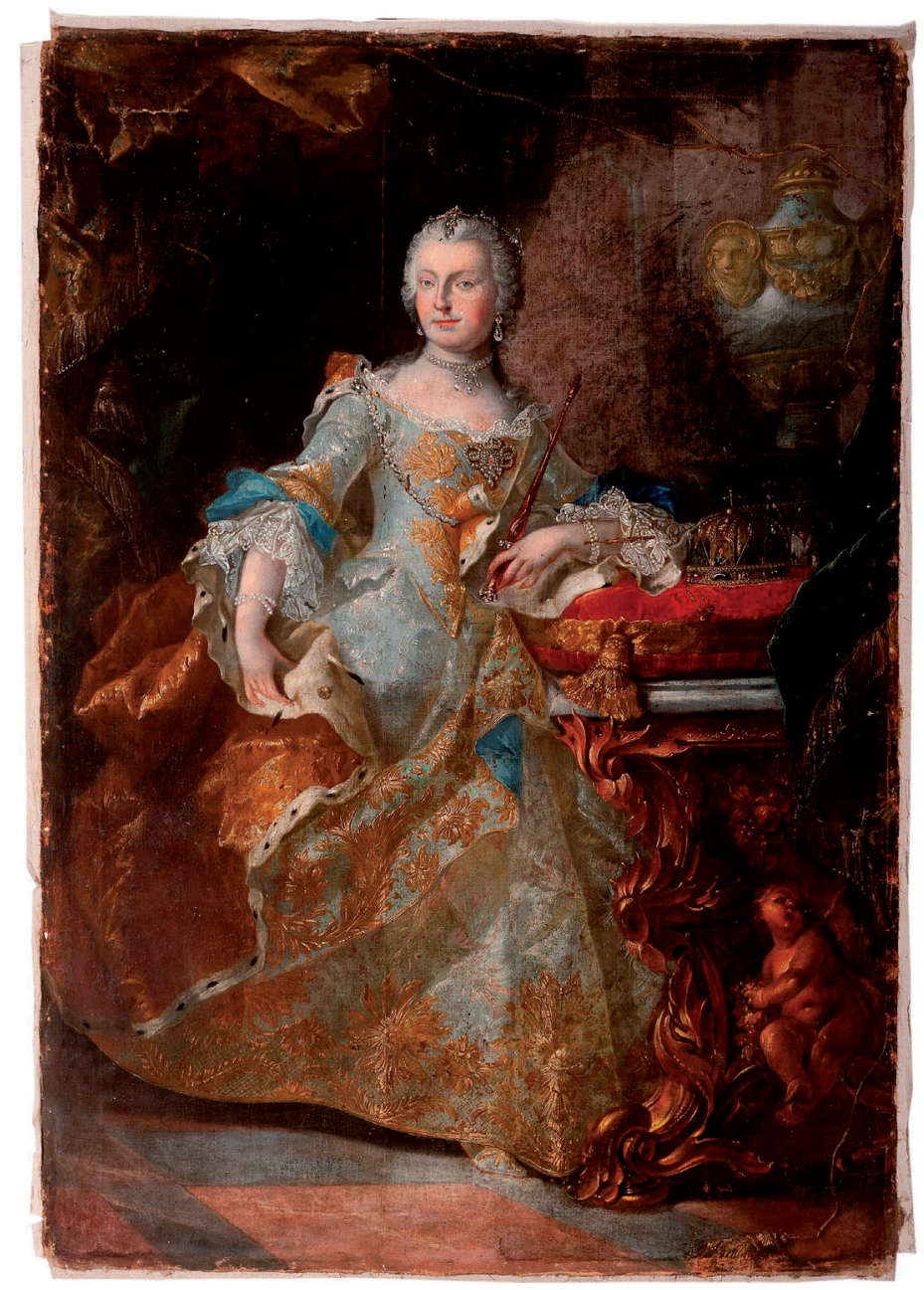

Slika 1. Stanje slike prije predmetne restauracije, nakon preuzimanja 2013. godine 


\section{ISTRAŽIVAČKI RADOVI NA SLICI}

Zadnja nedovršena restauracija iz 1993. god. popraćena je nepotpunom i nejasnom dokumentacijom, te nije bilo moguće sa sigurnošću utvrditi zone preslika i opravdanost njegovog potpunog ili djelomičnog uklanjanja. U predmetnoj je restauraciji konstatirano da je uklonjena zelena boja s haljine i tirkizno plava s desnog rukava, te je djelomično uklonjena tamna pozadina ispod koje se nazire arhitektura i draperija. Stoga je bilo potrebno utvrditi područje ostatka laka kao i postojanje originalnog potpisa autora, te sastav punila u prethodnoj intervenciji. Pristupilo se istraživačkim radovima koji su obuhvaćali IC i UV snimke, stratigrafiju slikanog sloja, probe uklanjanja sloja potamnjelog laka s nečistoćama i ostacima preslika u lijevom gornjem dijelu slike, te probe uklanjanja starih zakita.

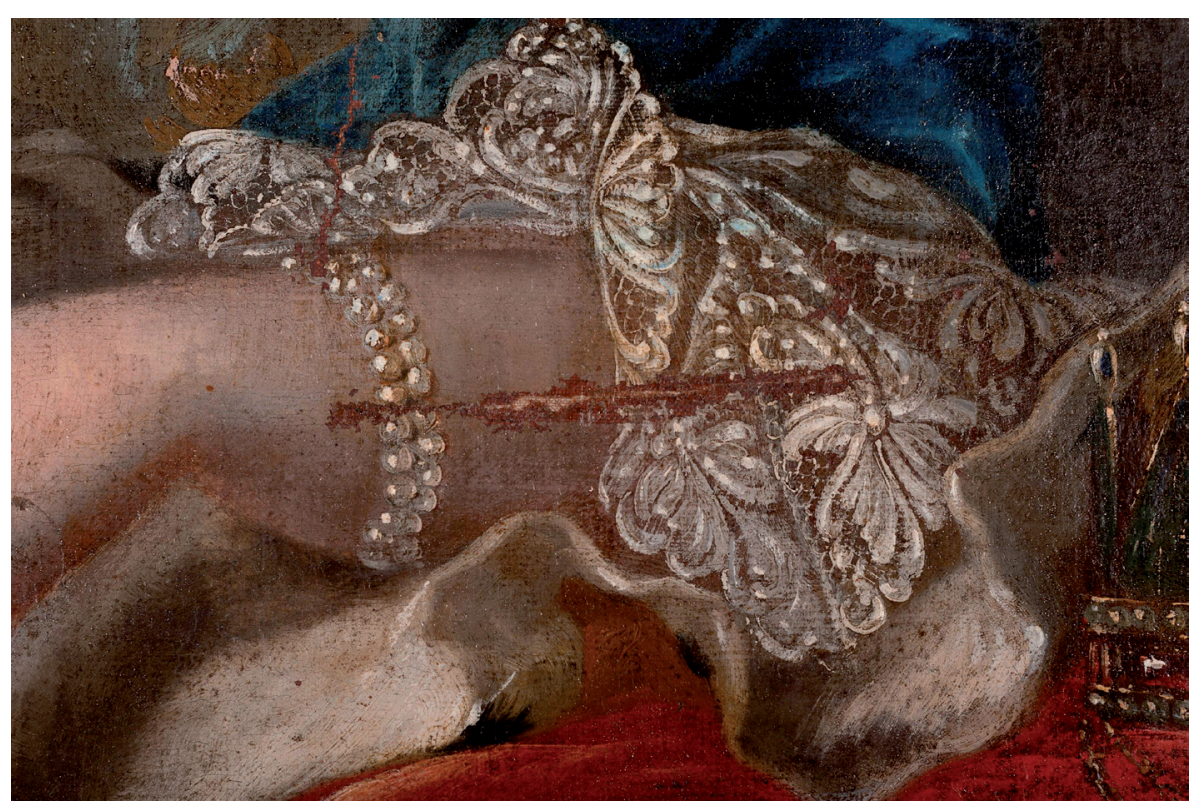

Slika 2. Detalj s perforacijom platna. Dio rukava u plavoj boji je djelomično preslikan, što je vidljivo i na fotografiji mikropresjeka uzorka uzetog $s$ tog dijela slike (uzorak br. 2, sl. 10) 


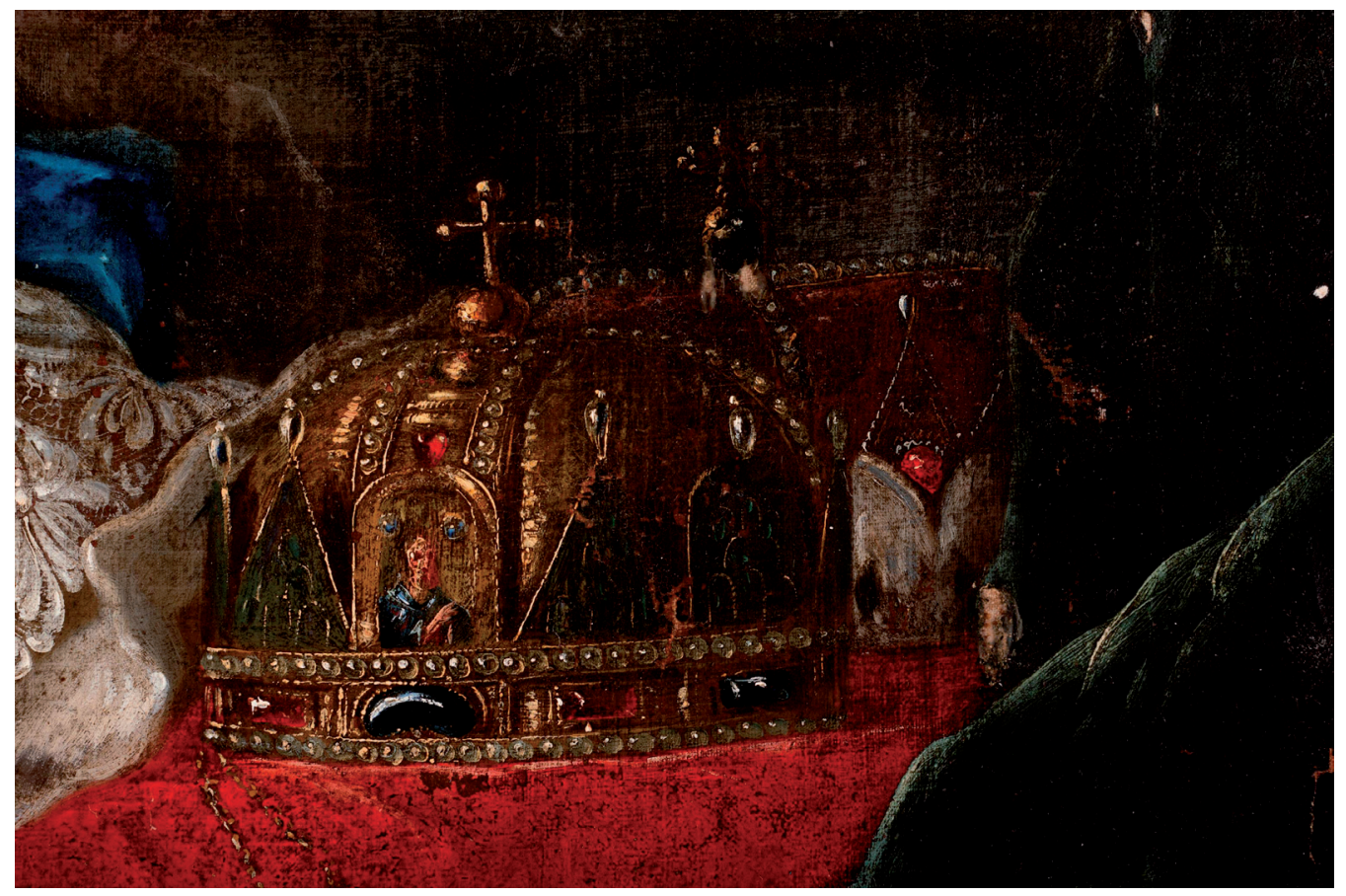

Slika 3. Detalj slike na kojem se mogu vidjeti ostaci potamnjelog laka na slikanoj površini, što se naročito očituje na obje krune, te na području iza njih 


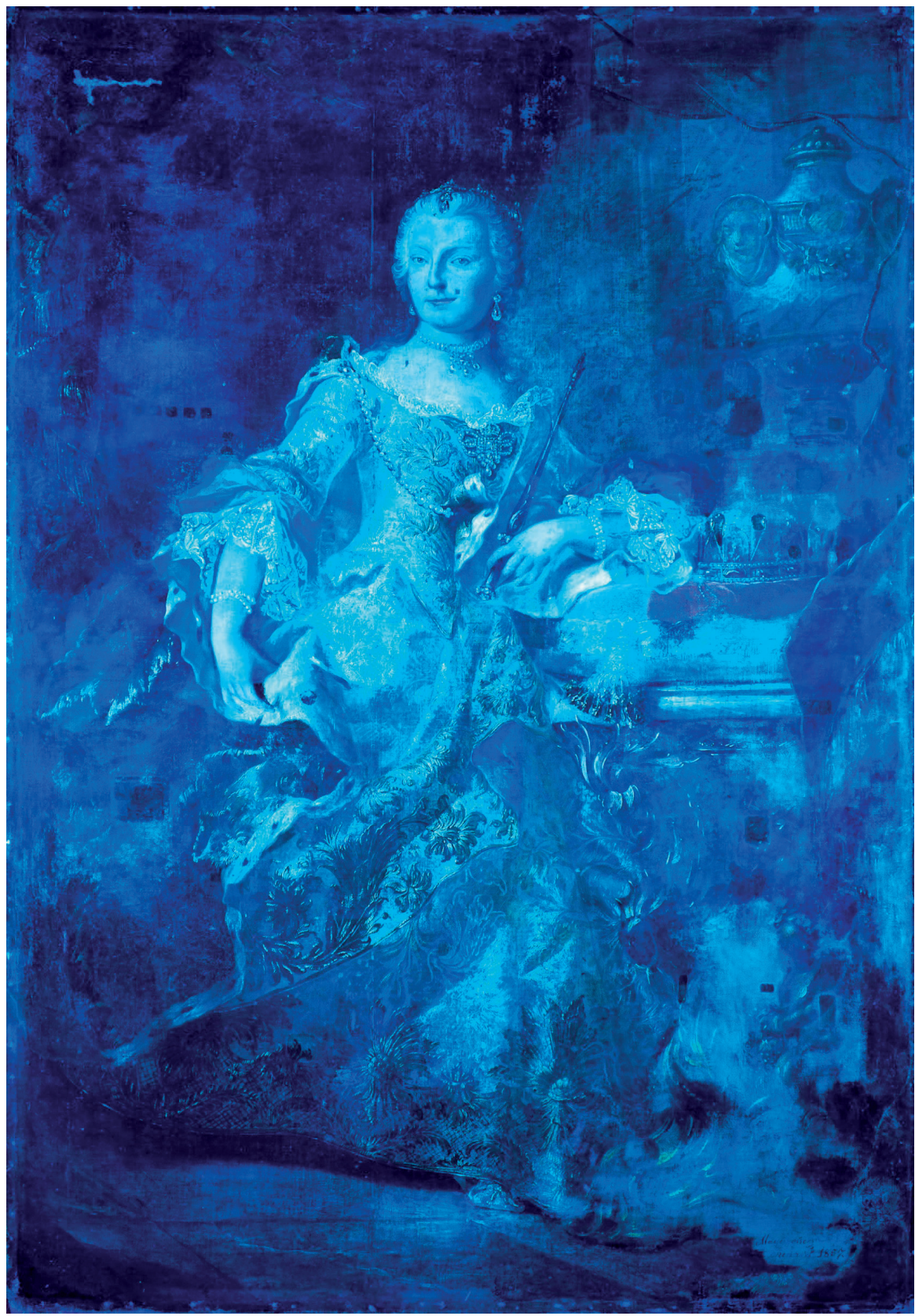

Slika 4. UV snimka totala s vidljivim tamnijim tonovima koji ukazuju na zone preslika, kao i na ostatke debljeg sloja starog laka 


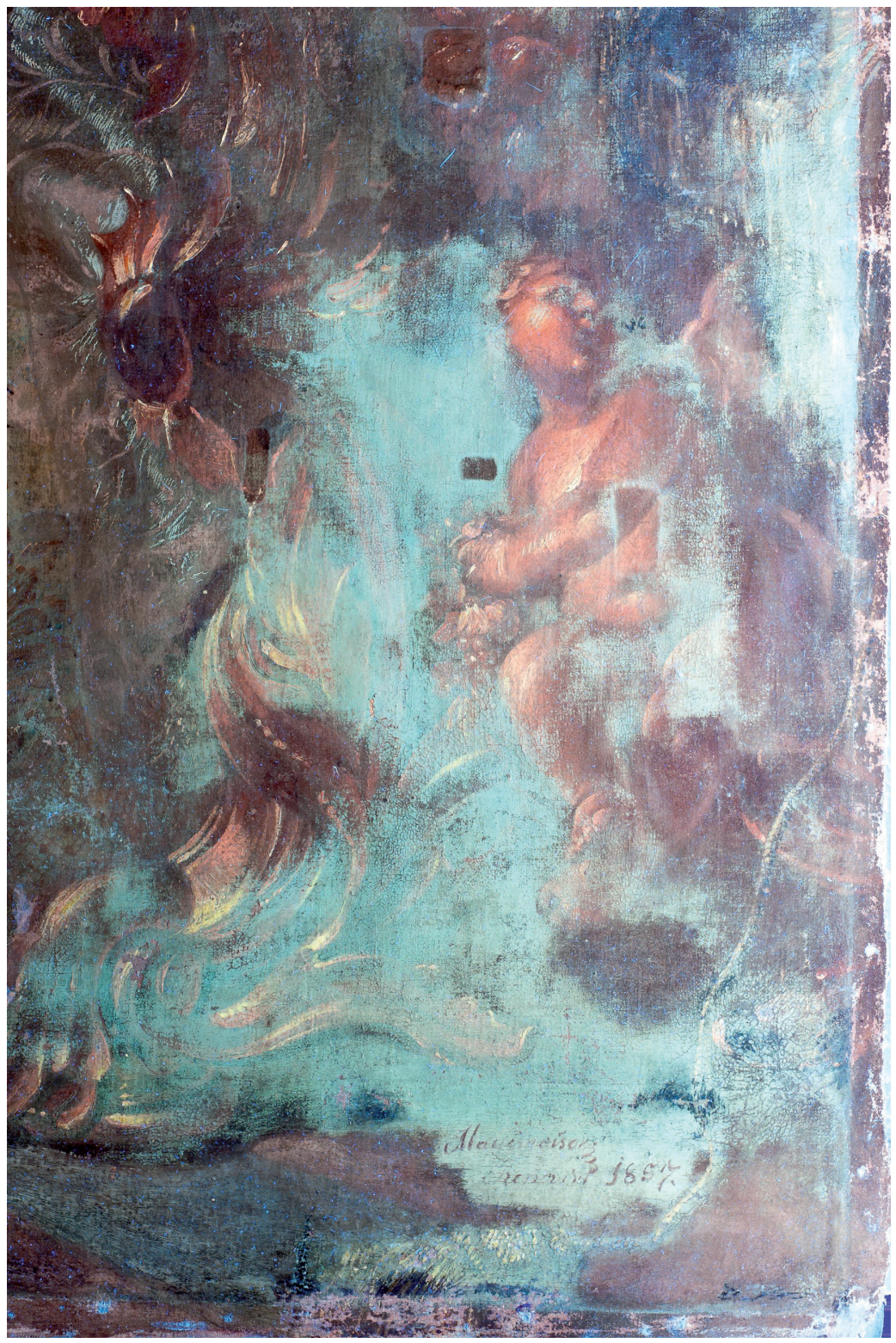

Slika 5. UV snimka detalja sa svijetlim tonovima koji ukazuju na slojeve laka iz obje ranije restauracije. Tamne sonde na snimci detalja prikazuju probe topivosti, odnosno sloj uklonjenog laka. U donjem desnom kutu vidljiv je potpis slikara Mayerwiesera s godinom tadašnje obnove slike. Potpis se nalazi preko preslika i sloja laka 


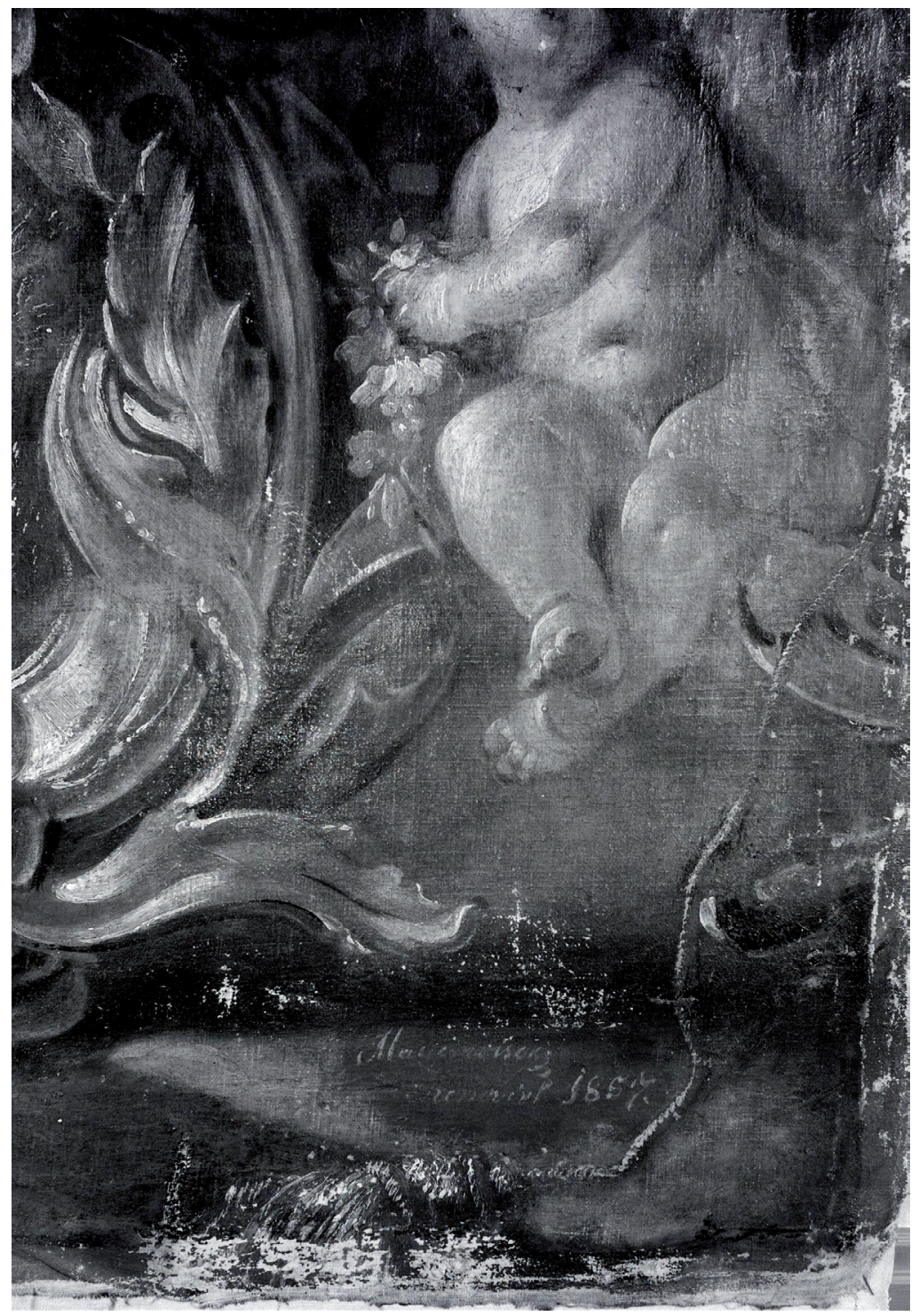

Slika 6. IC snimak detalja slike sa svijetlim tonovima koji nam ukazuju na oštećenja i zakite u sloju podloge. U zoni potpisa vidljiv je tamniji ton, što nam ukazuje na preslik. Signatura slikara Mayerwiesera koji je prvi obnavljao sliku, nalazi se na sloju laka iz čega se može zaključiti da je većina radova i preslika izvedena 1857. godine. IC i UV snimkama nije se utvrdilo postojanje originalnog potpisa ispod sloja preslika i laka uz donji rub slike. 


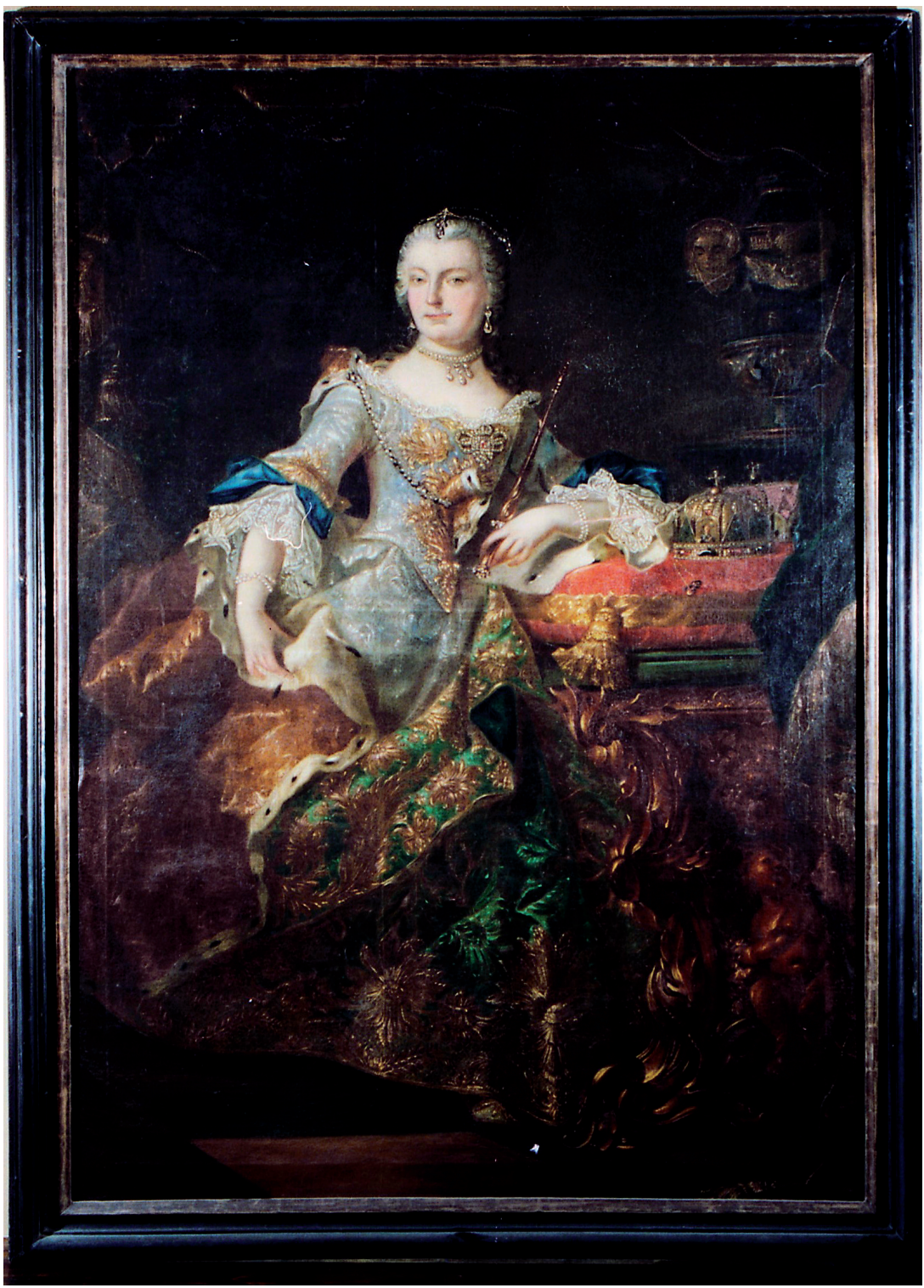

Slika 7. Fotografija totala preuzeta iz stare dokumentacije koja je pratila radove u prethodnoj restauraciji, a prikazuje stanje slike iz 1993. godine prije tadašnje restauracije. Na fotografiji su vidljivi slojevi starog laka, ali i brojni preslici kao što su zeleni tonovi na haljini, tirkizno plavi tonovi na rukavima i tamno smeđi slojevi boje na pozadini oko portreta. 


\section{REZULTATI ISTRAŽIVAČKIH RADOVA}

Uspoređujući skromnu pisanu i foto dokumentaciju iz 1993., komparativni materijal i dobivene rezultate predmetnih istraživačkih radova, možemo zaključiti da je u prethodnoj restauraciji s haljine uklonjen debeli sloj zelene boje i djelomično crno smeđi sloj koji je i dalje najizraženiji u gornjem dijelu slike. $\mathrm{S}$ preslika u slojevima plave boje koji se nalazio na desnom rukavu, u potpunosti je uklonjen tirkizni sloj, dok se na lijevom rukavu nije u potpunosti uklanjao. Najviše ostataka preslika nađeno je u donjem desnom dijelu slike. Na nekim površinama slikanog sloja, sloj starog potamnjelog laka s lazurama nije u potpunosti uklonjen. Nove intarzije lanenog platna kao i dodani rubovi lijepljeni su polivinil acetatom. Stratigrafskom analizom presjeka slikanog sloja može se konstatirati da je slika u restauraciji 1857. godine većim dijelom tonirana tamnom lazurom u čijem sastavu je pronađeno saharidno i proteinsko vezivo. Toniranje je izvedeno bez prethodnog uklanjanja naslaga nečistoće i požutjelog laka (uzorak br. 1). Lice i ruke su djelomično preslikani. Dijelovi haljine su naglašeni zelenim tonom, a rukavi tirkizno plavim. Analize XRF snimaka ostataka zelenog sloja boje s haljine pokazale su prisustvo barijeve bijele i kromoksid zelene. Ovi pigmenti su otkriveni početkom 19. stoljeća, (francuski kemičar Guyton de Morveau, te njemački ljekarnik i kemičar Carl Scheele prvi su prepoznali te pigmente) $)^{5}$, te nam taj podatak potvrđuje prethodnu konstataciju o prisutnosti velike količine preslika, što je tada, u 19. stoljeću bio čest slučaj. Na licu slike također su prisutni i ostaci voštanih i uljnih zakita iz prve restauratorske intervencije izvedene 1857. godine.

Probe topivosti preslika otapalima različitih Fd vrijednosti ${ }^{6}$ pokazale su dobre rezultate, što je omogućavalo optimalno uklanjanje starog laka, preslika, alteriranih retuša, te voštanih i uljnih zakita. U donjem desnom kutu slike, u sloju preslika, vidljiva je pomalo nečitka signatura slikara Mayerwiesera koji je 1857. „obnovio“ portret Marije Terezije (Mayerwieser renoviert 1857.). U dostavljenoj dokumentaciji iz 1993. godine navedeno je da je Mayerwieser u donjem desnom kutu slike potpisao slikara Meytensa (Meytensen pinxit 1857.) prilikom obnove 1857. godine. U predmetnoj je restauraciji ustanovljeno da se zbog osjetljivosti originalnog slikanog sloja preslik u tom dijelu slike neće uklanjati, već će se lak i prljavština istanjiti u razini istog.

5 An atlas of rare and famililar colour, The Harvard Art Museum, published by Atelier Editions, LA, California, 2017. 89., 181.

$6 \quad \mathrm{Fd}$ - jedna od oznaka koje se odnose na vrijednost za testove topivosti u vezivima i otapalima. 
MAŠA MARIA ŠTROK: Konzervatorsko-restauratorski radovi na portretu Marije Terezije ...

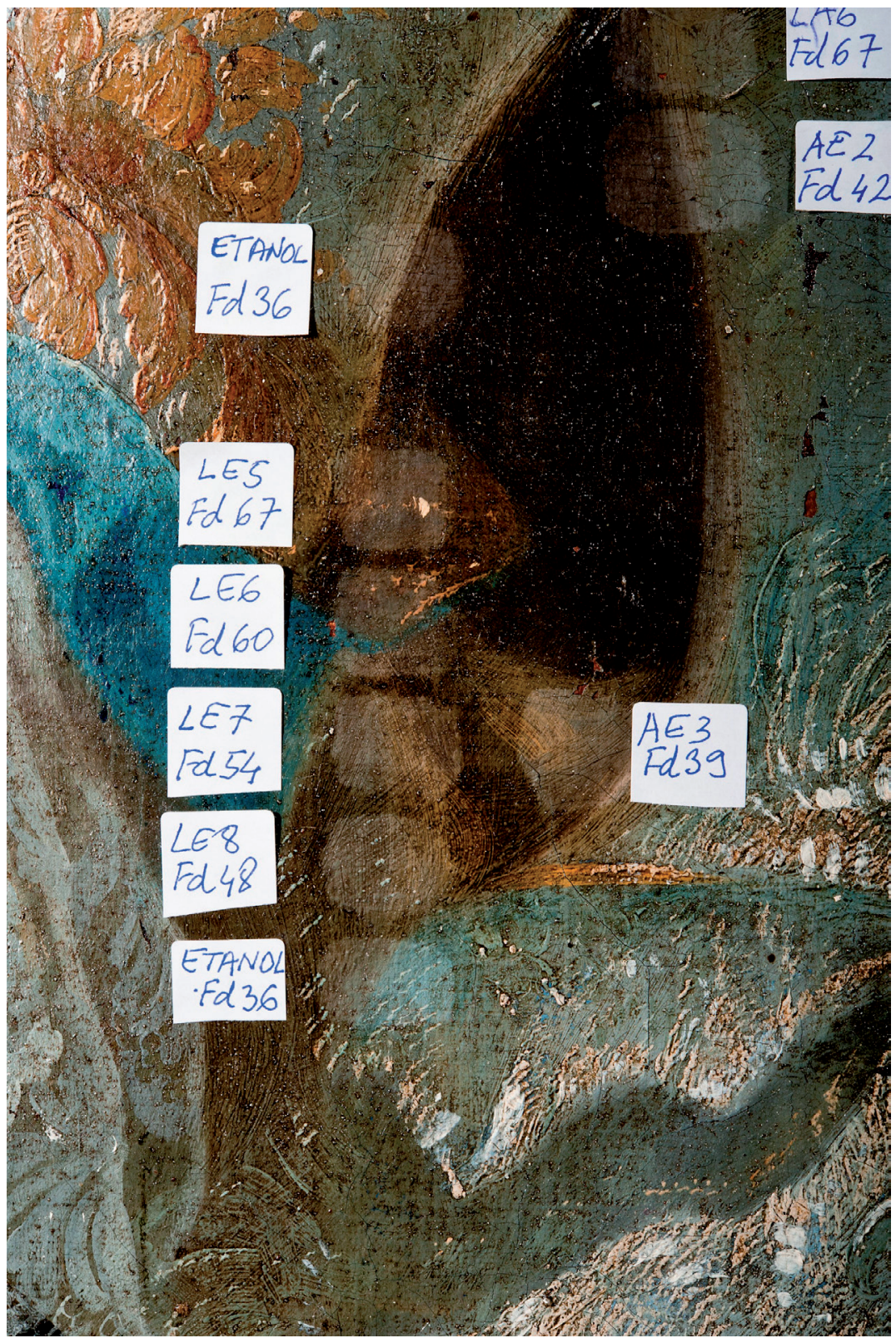

Slika 8. Detalj slike koji prikazuje probe topivosti, kako bi se došlo do optimalnih otapala za uklanjanje površinske nečistoće, laka, preslika, alteriranih retuša, te voštanih i uljnih zakita. 


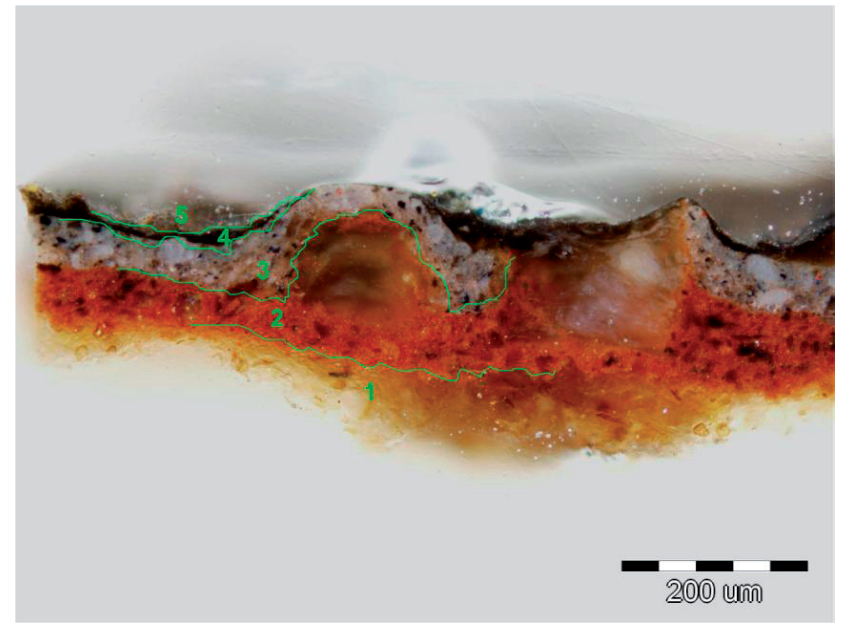

Slika 9. uzorak br. 1

5. smeđi sloj (umbra) - preslik; 4. tamno smeđi sloj - prljavština;

3. sivkasto ružičasti sloj sa zrncima crvenog, crnog i plavog pigmenta - originalni sloj;

2. crveno narančasti sloj (crveni oker) - podslik;

1. žuti sloj - preparacija

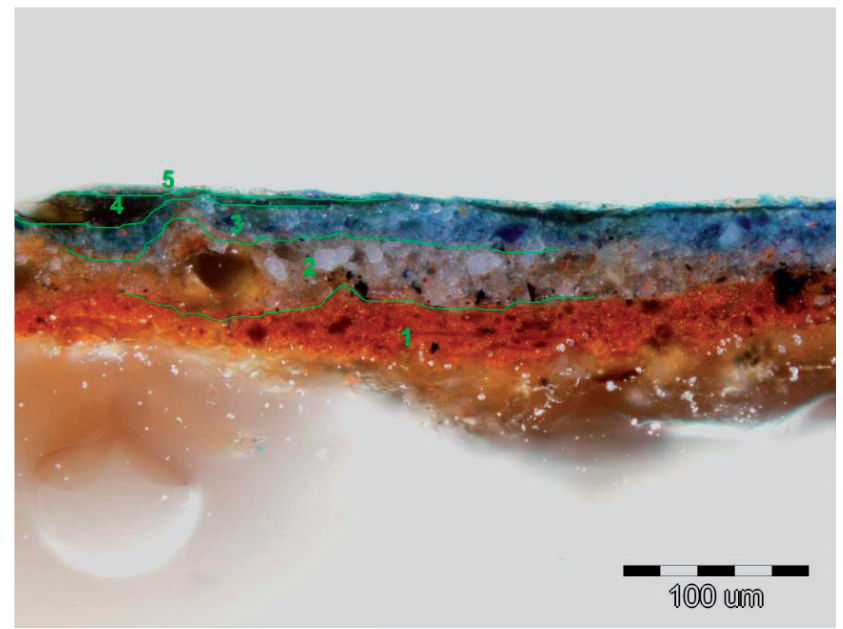

Slika 10. uzorak br. 2

5. plavo zeleni sloj - preslik; 4. prozirni tamno smeđi sloj - lak; 3. plavi sloj sa zrncima plavog i bijelog pigmenta (pruska plava, olovna bijela) - originalni sloj; 2 . sivkasto ružičasti sloj sa zrncima crvenog, crnog i plavog pigmenta (olovna bijela, crveni oker, organska crna?) - podslik; 1. crveno narančasti sloj (crveni oker) - preparacija 


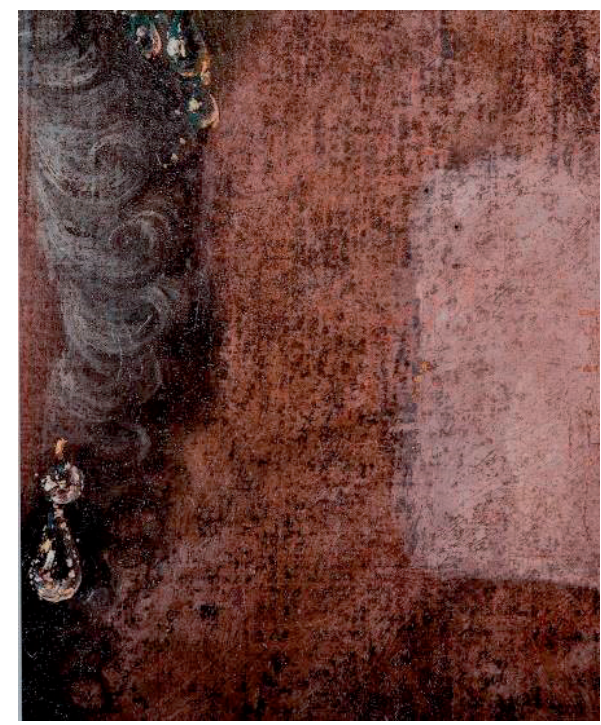

Slika 11. Sondiranjem preslika vidljiv je znatno svijetliji ton originalne pozadine. $\mathrm{Na}$ ovu činjenicu ukazuje i fotografija mikropresjeka uzorka slikanog sloja sa spomenutog dijela slike (uzorak br. 1, sl. 9). Tamni sloj boje u svom sastavu ima saharidno i proteinsko vezivo.

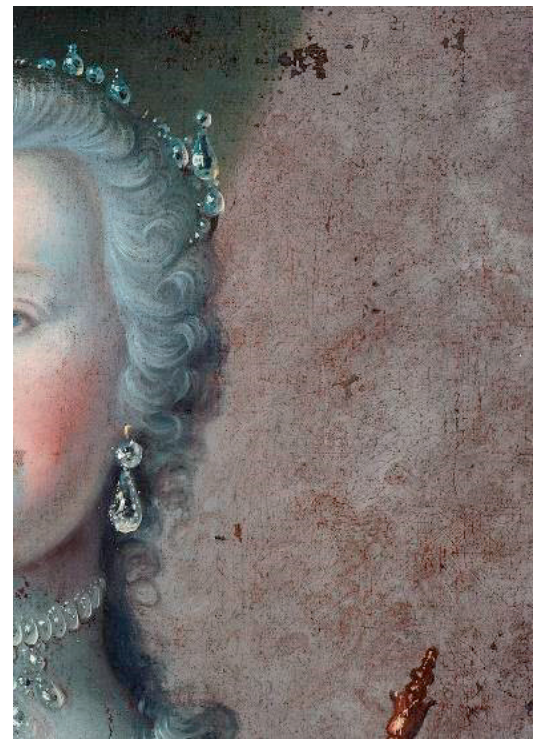

Slika 12. Detalj slike prilikom gradacije uklanjanja prljavštine, laka i preslika.

Otkrivena je znatno svijetlija pozadina oko lika Marije Terezije. 
Rezultati XRF analize

\begin{tabular}{|c|c|c|c|c|c|}
\hline $\begin{array}{l}\text { Mjesto } \\
\text { analize }\end{array}$ & $\begin{array}{c}\text { Boja } \\
\text { pigmenta }\end{array}$ & $\begin{array}{l}\text { Pretpostavlj } \\
\text { eni pigment }\end{array}$ & $\begin{array}{c}\text { Detektiran } \\
\text { i elementi } \\
\text { (elementi } \\
\text { u } \\
\text { tragovima) }\end{array}$ & $\begin{array}{c}\text { Fotografija mjesta } \\
\text { analize }\end{array}$ & XRF spektar \\
\hline 1 & Zelena & $\begin{array}{c}\text { Olovna } \\
\text { bijela, } \\
\text { barijeva } \\
\text { bijela, } \\
\text { krom oksid } \\
\text { zelena }\end{array}$ & $\begin{array}{c}\mathrm{Pb}, \mathrm{Ba}, \mathrm{Fe} \\
(\mathrm{Cr}, \mathrm{Ca}, \\
\mathrm{Sn}, \mathrm{K}, \mathrm{Ca})\end{array}$ & & \\
\hline 2 & $\begin{array}{l}\text { Svijetlos } \\
\text { međa }\end{array}$ & $\begin{array}{c}\text { Olovna } \\
\text { bijela, } \\
\text { željezni } \\
\text { oksid, } \\
\text { pigment na } \\
\text { bazi arsena? }\end{array}$ & $\begin{array}{c}\mathrm{Pb}, \mathrm{Fe}, \mathrm{As} \\
(\mathrm{Ca}, \mathrm{K}, \mathrm{Si}, \\
\mathrm{Sr}, \mathrm{Sn}, \mathrm{Ti}, \\
\mathrm{Mn}, \mathrm{Ni}, \\
\mathrm{Cu}, \mathrm{Zn})\end{array}$ & 8 & \\
\hline 3 & Smeđa & $\begin{array}{c}\text { Olovna } \\
\text { bijela, } \\
\text { željezni } \\
\text { oksid, } \\
\text { pigment na } \\
\text { bazi arsena? }\end{array}$ & $\begin{array}{c}\mathrm{Pb}, \mathrm{As}, \\
\mathrm{Fe}, \mathrm{Zn}, \mathrm{Ca} \\
(\mathrm{Si}, \mathrm{Sr}, \mathrm{K} \text {, } \\
\mathrm{Ti}, \mathrm{Mn}, \\
\mathrm{Cu}, \mathrm{Hg})\end{array}$ & & \\
\hline 4 & $\begin{array}{l}\text { Zeleno } \\
\text { smeđa }\end{array}$ & $\begin{array}{c}\text { Olovna } \\
\text { bijela, } \\
\text { zelena } \\
\text { zemlja? }\end{array}$ & $\begin{array}{c}\mathrm{Pb}, \mathrm{Fe}, \mathrm{Ca} \\
(\mathrm{Al}, \mathrm{Si}, \mathrm{K} \text {, } \\
\mathrm{Mn}, \mathrm{Cu}, \\
\mathrm{Zn}, \mathrm{Hg}, \\
\mathrm{Sr})\end{array}$ & & \\
\hline 5 & Plava & $\begin{array}{l}\text { Olovna } \\
\text { bijela, } \\
\text { prusko } \\
\text { plava? }\end{array}$ & $\begin{array}{c}\mathrm{Pb}, \mathrm{Fe} \\
(\mathrm{Hg}, \mathrm{Cu}, \\
\mathrm{Ca}, \mathrm{K}, \mathrm{Sr}, \\
\mathrm{Sn})\end{array}$ & & \\
\hline 6 & Crvena & $\begin{array}{c}\text { Olovna } \\
\text { bijela, } \\
\text { cinober, } \\
\text { pigment na } \\
\text { bazi kroma }\end{array}$ & $\begin{array}{l}\mathrm{Pb}, \mathrm{Hg}, \mathrm{Cr} \\
(\mathrm{Fe}, \mathrm{Ca}, \\
\mathrm{Sn}, \mathrm{Si})\end{array}$ & & \\
\hline
\end{tabular}




\section{KONZERVATORSKO - RESTAURATORSKI RADOVI NA SLICI}

\section{Uklanjanje površinske nečistoće, laka, preslika,} alteriranih retuša i starih zakita.

Prilikom istraživačkih radova ustanovljeno je da se površinska nečistoća $s$ lica slike najbolje uklanja blagim otapalima ( $\mathrm{pH7}$ ) na bazi vode, a ostaci preslika i starih požutjelih lakova kombinacijom otopine odgovarajuće Fd vrijednosti i emulzijom. lako je u ranijoj restauratorskoj intervenciji veći dio preslika uklonjen, tamniji nanosi boje i dalje su bili vidljivi po cijelom formatu slike. Naročito se isticao tamniji preslik u gornjem lijevom uglu slike. Uklanjanje preslika izvodilo se u nekoliko navrata nanošenjem odgovarajuće emulzije, te skidanjem i neutralizacijom iste. Prilikom čišćenja lica slike, ustanovljeno je također da je originalna lazura mjestimice istanjena što se naročito očituje u dekorativnim elementima na draperiji.

Neke perforacije i oštećenja su u ranijim restauratorskim intervencijama rekonstruirani različitim punilima kao što su vosak i višeslojni uljni sastavi, a mjestimično su bili nanijeti i preko originalnog slikanog sloja. U predmetnoj su se restauraciji tvrdokorniji zakiti uklanjali mehanički, te kombinacijom otopine odgovarajuće Fd vrijednosti i emulzijom. Ostaci takvih tvrdokornijih uljnih zakita koji su prilikom čišćenja mogli ugroziti postojanost slikanog sloja, nivelirani su do razine istog. Zakiti koji su bili voštanog sastava odstranjeni su blažim otapalima. Uklanjanje preslika izvodilo se u više navrata nanošenjem odgovarajuće emulzije, te skidanjem i neutralizacijom iste.

Za vrijeme čišćenja lica slike koje je izvedeno u nekoliko etapa, slika je bila napeta na pomoćni okvir. Signatura u donjem desnom kutu očišćena je samo površinski, stanjivanjem starog požutjelog laka vrlo blagim otapalom radi osjetljivosti slikanog sloja.

\section{Sanacija nosioca, podloge i boje}

Nakon istraživačkih radova i čišćenja lica slike uslijedilo je skidanje umetaka platna i platnenih traka s rubova na poleđini slike. Umetci iz prethodne restauratorske intervencije nisu pratili formu oštećenja, bili su četvrtastog oblika, fiksirani vrlo jakim plastificiranim ljepilom na originalno platno. Kao i umetci platna i trake na rubovima nisu bile odgovarajuće formirane, te su, međusobno se preklapajući, nejednakih širina i dužina, također bile fiksirane neadekvatnim tvrdokornim ljepilom (oko $3 \mathrm{~cm}$ preko unutarnjeg ruba slike).

Nakon uklanjanja starih umetaka platna parcijalnim zagrijavanjem pomoću toplinske špatule, cijela poleđina slike očišćena je mehaničkim i djelomično ke- 
mijskim putem (uklanjanje voštane paste). Slika je zatim tretirana na toplinskom vakuum stolu radi ravnanja i dodatne konsolidacije. Prilikom tog postupka, spustile su se i blago izdignute krakelire na licu slike. Uslijedilo je saniranje oštećenja novim umetcima ranije prepariranog lanenog platna, iskrojenim po obliku mehaničkih oštećenja. Umetci su u razini originalnog platna fiksirani beva filmom i tankim japan papirom, a porezotine su spajane pomoću lanenih niti i pulveriziranog ljepila toplinskom špatulom.

Nakon sanacije oštećenja, slika je s poleđine, kao i novo laneno platno, tretirana sintetskim ljepilom nakon čega je dublirana na toplinskom vakuum stolu. Nakon dubliranja i dodatnog ravnanja, oštećenja su u sloju preparacije rekonstruirana pomoću metil-celuloznog kita s odgovarajućim pigmentom i manjom količinom akrilnog ljepila. Prilikom sanacije oštećenja odgovarajućim punilom, u završnom se sloju pratila struktura platna. Slika je zatim napeta na novo izrađeni drveni klinasti podokvir. Podlaganje retuša izvedeno je u gvaš tehnici, u svijetlijoj nijansi lokalnog tona. Nakon podlaganja retuša slika je izolirana smolnim industrijskim lakom, a završni retuš izveden je lazurnim smolnim bojama. Mjesta na slici gdje nedostaju originalne lazure djelomično su povezivana retušem u smolnim lazurama u tanjim nanosima, bez podlaganja gvašem. Nakon završnog retuša, cijelo lice slike lakirano je kombinacijom industrijskog sjajnog i mat laka u jednakom omjeru radi dodatne zaštite i izolacije slikanog sloja, kao i odgovarajućeg sjaja koji je portret zahtijevao.

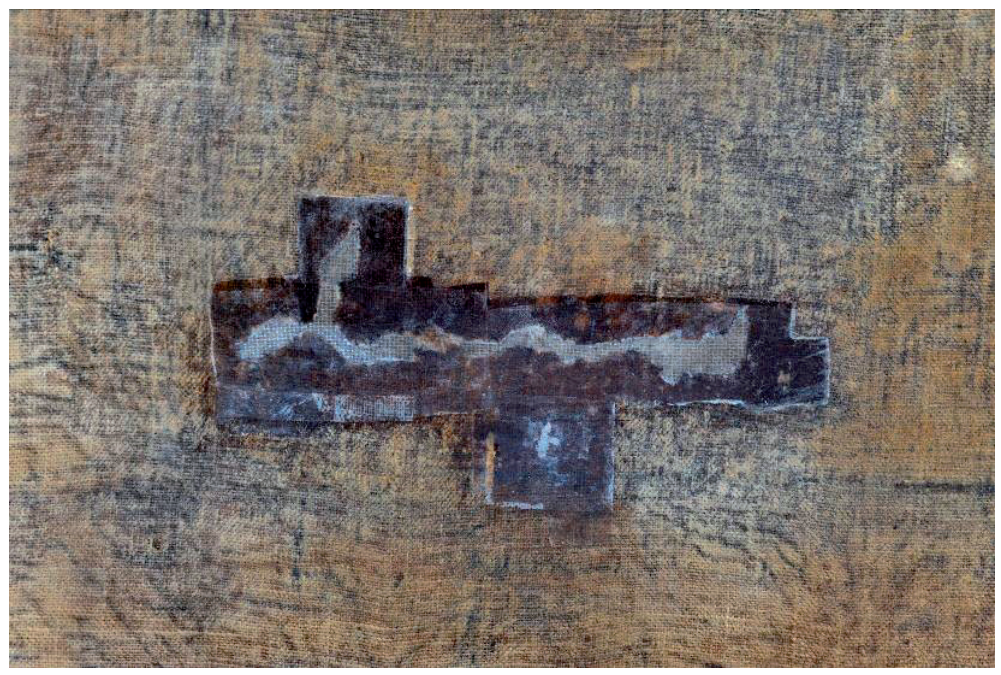

Slika 13. Detalj poleđine u tijeku sanacije oštećenja pomoću novih iskrojenih umetaka od lanenog platna i beva filma u kombinaciji s tankim japan papirićima. 


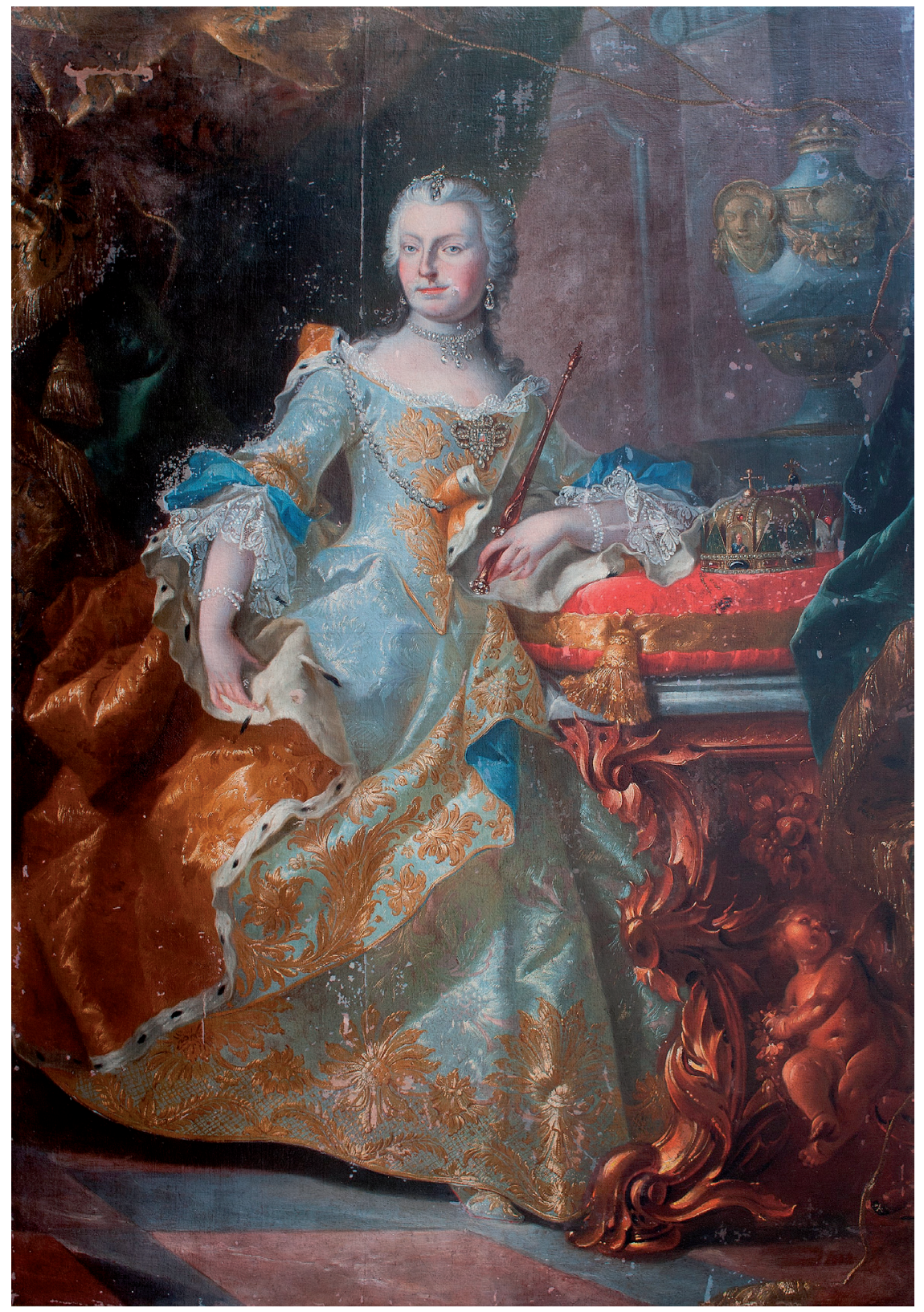

Slika 14. Stanje slike nakon rekonstrukcije oštećenih dijelova pomoću odgovarajućeg punila i podlaganja retuša u gvaš tehnici 
Radovi Zavoda za znanstveni rad HAZU Varaždin; br. 30, 2019, str. 259-282

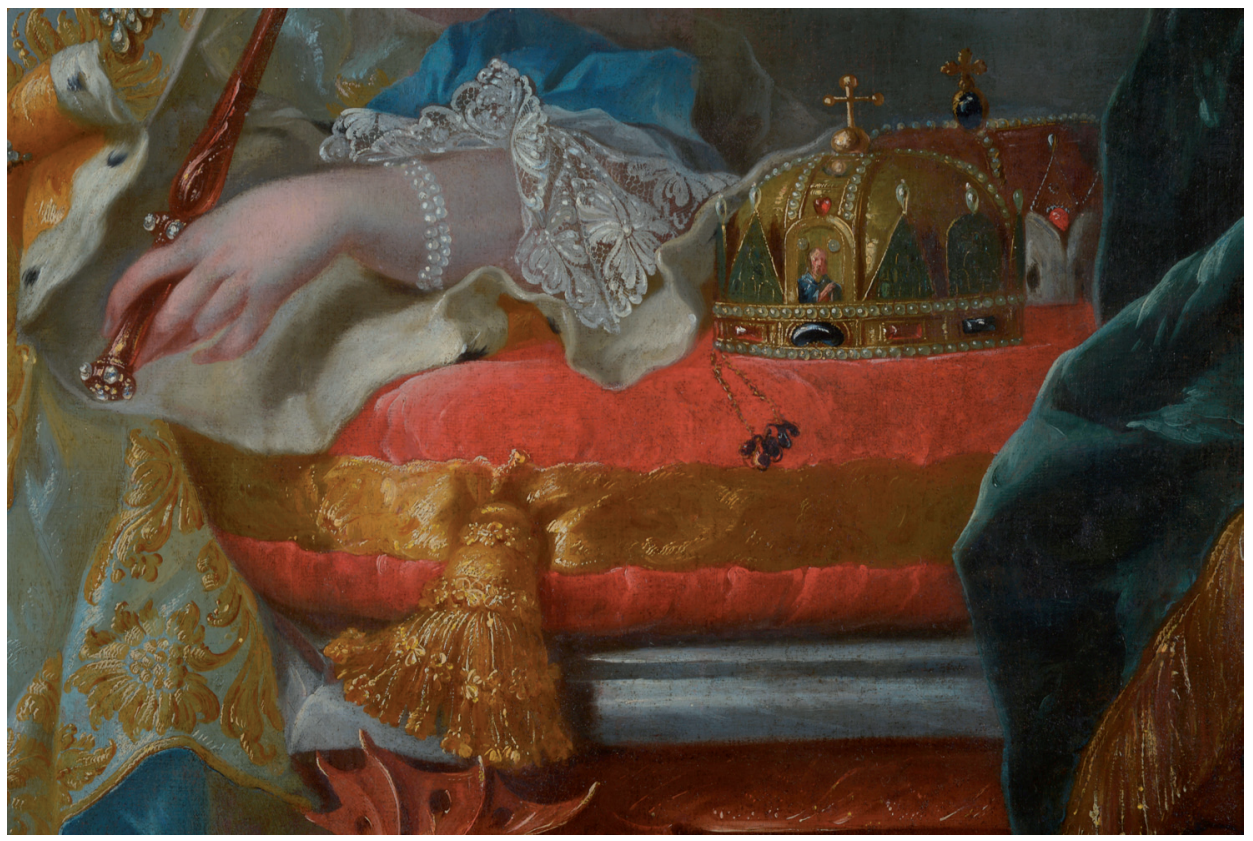

Slika 15. Detalj slike nakon završnog retuša smolnim lazurama 


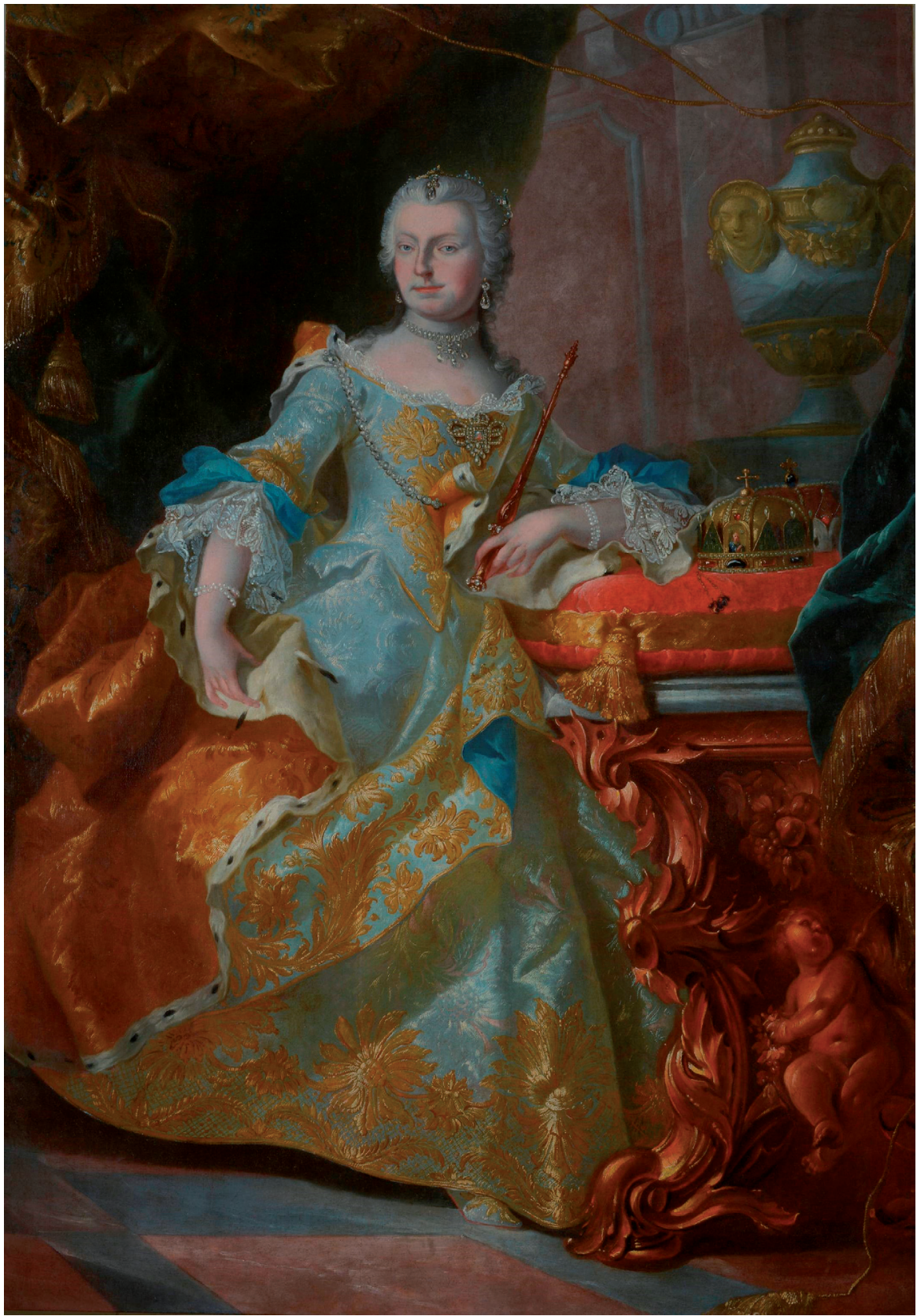

Slika 16. Total nakon završnog retuša smolnim lazurama 


\section{LITERATURA}

1/ Varaždin pod krunom Habsburgovaca, Gradski muzej Varaždin, Varaždin, 2015. 104.-105., 140.

2/ Marijana SCHNEIDER, Portreti 16-18. stoljeća, Povijesni muzej Hrvatske, Zagreb, 1982., 27.

3/ Krešimir FILIĆ, Varaždinski muzej, u spomen 20-godišnjice postojanja „Varaždinskog muzealnog društva" , Varaždin, 1943. 44., 52.-53.

4/ Marijana SCHNEIDER, Portreti 1800 - 1870., Povijesni muzej Hrvatske, Zagreb, 1973. 28.-29.

5/ An atlas of rare and famililar colour, the Forbes pigment collection, The Harvard Art Museum, published by Atelier Editions, LA, California, 2017. 89., 181.

6/ Galerija likovnih umjetnosti Osijek, monografija-zbornik, Osijek 1987.

7/ http://en.wikipedia.org/wiki/Martin_van_Meytens - pristupila 24.12. 2018.

\section{SAŽETAK \\ KONZERVATORSKO-RESTAURATORSKI RADOVI NA PORTRETU MARIJE TEREZIJE IZ GRADSKOG MUZEJA VARAŽDIN}

U radu su obrađeni konzervatorsko-restauratorski radovi na portretu Marije Terezije iz prve polovine 18. stoljeća. Slika je pripisana radionici Martina van Meytensa. Tehnika slike je ulje na platnu, a portret prikazuje Mariju Tereziju koja je kao ugarsko-hrvatska i češka kraljica vladala u doba Habsburške Monarhije od 1740. do 1780. godine. U svojoj je vladavini uvela brojne reforme u vanjskoj i unutarnjoj politici. Slika potječe iz ranog razdoblja njezine vladavine, a prikazuje je cijelim stasom u slavljeničkoj brokatnoj odori. Stoji kraj bogato izrezbarenog stola na kojem se nalazi svečano ukrašen jastuk s dvjema položenim krunama austrijskih nadvojvoda. Visina slike je $203 \mathrm{~cm}$, a širina $140 \mathrm{~cm}$.

Specifičnost ove slike je da je imala dvije ranije restauratorske intervencije, 1857. i 1993. godine.

U donjem desnom kutu slike, u sloju preslika, vidljiva je teško čitljiva signatura koja se najbolje razaznaje uz pomoć makrofotografije, a glasi Mayerwieser renoviert 1857, dok se u dostavljenoj dokumentaciji iz 1993. tumači da se na slici nalazi naziv Meytensen pinxit 1857. kojeg je Mayerwieser potpisao prilikom obnavljanja slike iste godine. Taj nam podatak potvrđuje da je naziv Mayerwieser renoviert 1857. nastao prilikom prve restauracije na slici u izvedbi austrijskog slikara Ferdinanda (?) Mayerwiesera. Tijekom restauracije 2014. godine komisijski je utvrđeno da se taj potpis neće uklanjati radi osjetljivosti slikanog sloja u 
tom dijelu slike. Signatura u donjem desnom kutu očišćena je samo površinski, stanjivanjem starog požutjelog laka vrlo blagim otapalima.

Prilikom istraživačkih radova koja su uključivala tehnička ispitivanja i testove topivosti, zaključeno je da je u ranijim restauratorskim intervencijama uklonjena zelena boja s haljine i tirkizno plava s desnog rukava, a djelomično je uklonjena i tamna pozadina ispod koje se nazire arhitektura i draperija. S obzirom da je bilo potrebno utvrditi područje ostatka laka i preslika kao i sastav punila u prethodnoj intervenciji, pristupilo se dodatnim istraživačkim radovima koji su obuhvaćali IC i UV snimke, stratigrafiju slikanog sloja, probe uklanjanja sloja potamnjelog laka s nečistoćama i preslicima, te probe uklanjanja starih zakita.

Stratigrafska analiza presjeka slikanog sloja pokazala je da je slika u restauraciji 1857. godine većim dijelom tonirana tamnom lazurom u čijem je sastavu pronađeno saharidno i proteinsko vezivo. Toniranje je bilo izvedeno bez prethodnog uklanjanja naslaga nečistoće i požutjelog laka. Analize XRF snimaka ostataka zelenog sloja preslika s haljine otkrile su barijevu bijelu i krom oksid zelenu. Ti su pigmenti otkriveni početkom 19. stoljeća što potvrđuje prethodni zaključak o prisutnosti velike količine preslika.

Prilikom čišćenja prljavštine i preslika otkrivena je znatno svijetlija pozadina oko lika Marije Terezije.

Nakon istraživačkih radova, čišćenja lica i poleđine slike, parcijalno su skinuti umetci platna i platnenih traka s rubova na poleđini slike. Slika je tretirana na toplinskom vakuum stolu radi dodatne konsolidacije i ravnanja. Prilikom tog postupka, spuštene su i blago izdignute krakelire na licu slike. Oštećenja su sanirana novim umetcima ranije prepariranog lanenog platna, iskrojenim prema obliku oštećenja, a pukotine na platnu spajane su pomoću pulveriziranog ljepila toplinskom špatulom. Nakon sanacije oštećenja, slika je s poleđine, kao i novo laneno dublirno platno, tretirana sintetskim ljepilom nakon čega je dublirana na toplinskom vakuum stolu. Nakon tog su postupka sanirana oštećenja u sloju preparacije. Slika je na kraju napeta na novo izrađeni drveni, križni klinasti podokvir.

Podlaganje retuša izvedeno je u gvaš tehnici, u svijetlijoj nijansi lokalnog tona. Nakon podlaganja, slika je izolirana lakom. Završni retuš izveden je smolnim lazurama.

Osim po svojoj umjetničkoj vrijednosti, slika je specifična i po svojim ranijim restauratorskim intervencijama koje su izazvale mnoge polemike u pronalaženju optimalnih rješenja za predmetnu restauraciju i konzervaciju koja je dovršena 2014. godine.

Ključne riječi: Marija Terezija; Martin van Meytens; Mayerwieser; ulje na platnu; ranije restauratorske intervencije; istraživački radovi; restauracija; konzervacija. 


\section{SUMMARY}

\section{CONSERVATION AND RESTORATION OF THE PORTRAIT OF MARIA THERESA} FROM THE VARAŽDIN CITY MUSEUM

This article is about the conservation and restoration carried out on a portrait of Maria Theresa from the 18th century attributed to the workshop of painter Martin van Meytens.

The painting is an oil on canvas and portrays Maria Theresa, Hapsburg sovereign of Austria, Hungary, Croatia, Bohemia, Transylvania, Mantua, Milan, Lodomeria and Galicia, the Austrian Netherlands and Parma. By marriage, she was Duchess of Lorraine, Grand Duchess of Tuscany and Holy Roman Empress. During her rule $(1740-1780)$ she introduced a number of reforms in foreign and domestic policies.

This painting, painted during the first few years of her rule, shows her whole posture in celebratory brocade robe, as she stands next to a richly carved table with a solemnly decorated cushion and two crowns of the Austrian archduke. The dimensions of the painting are $203 \mathrm{~cm} \times 140 \mathrm{~cm}$ (height/width).

The painting had undergone two previous restorations, in 1857 and 1993. Based on documentation, an interesting detail was added during the 1993 restoration: in the lower right corner of the painting, in the overpaint layer there is a visible signature Meytensen pinxit 1857 - even though the painter died in 1770. It is therefore assumed that he was signed during the first restoration of the painting in 1857, led by painter Mayerwieser. During the last restoration in 2014, it was concluded that this signature is not correct, the correct one is Mayerwieser renoviert 1857. Because of the fragility of painted layer on this part of the canvas, the signature was cleaned only superficially by thinning of the yellowy varnish with a mild solution.

Because of the incomplete and unclear documentation following the 1993 restoration, it was very hard to determinate all of the zones with layers of overpaint and validate the decision to remove them completely or only partially. After the probing it was concluded that the green color from the robe and turquoise color from the right sleeve were both removed during previous restorations. The dark background with visible architecture and drapery was also partially removed. Additional probes, including IC and UV scans, stratigraphy of the painted layer, removal probing of tarnished varnish with impurities and overpaint, were conducted to determine the zones of preserved varnish and overpaint as well as the quality of fill composition in the previous intervention. 
Stratigraphic cross-sectional analysis showed that during 1857 restoration, the painting was tanned with dark glaze based on saccharides and protein binder. Toning was executed without the removal of dirt, rust and old varnish. Analysis of XRF images of the green overpaint layer from the robe detected barium white and green chromium pigments. These pigments originated in the early 19th century which proves the previous conclusion of a huge overpaint presence.

Considerably brighter background behind the image of Maria Theresa was discovered during the removal of impurities and overpaint.

After the probing and cleaning of the face of the painting, canvas inserts were partially removed as well as linen strips from the edges on the back of the painting. Inserts from the previous restoration works did not follow the form of damage, they were square in shape and attached with hardened, inadequate glue that was unevenly applied on the original canvas. Linen strips were also inadequately formed so they all had to be removed.

The whole back of the painting was mechanically and chemically cleaned, and then strainghtened on the thermal vacuum table. During the procedure, even craquelures on the face of the painting descended. All damage was repaired with prefabricated linen adjusted to the shape of the damage. Inserts in the level of original canvas were fixed with Beva Film and Japanese paper, and the cracks on the canvas were bonded with powdered adhesive applied with heat shrink.

After the damage was repaired, both face and the back of the painting were treated with a synthetic adhesive, and fixed on a new canvas doubled on the thermal vacuum table.

After doubling and additional straightening, damages in the ground layer were reconstituted with methyl cellulose filler of the appropriate pigment and a smaller amount of acrylic adhesive. During this process, the structure of the canvas was followed. Finally the painting was monuted on the new wooden underframe.

Retouche underlying was executed in gouache technique, in a lighter shade of the local tone.

After that, the painting was isolated in varnish. The final retouching was executed in resin glaze, and the painting was additionally protected with a combination of glossy and matte lacquer in equal proportions.

Except for its artistic value, the painting is unique because of earlier restorations that caused many discussions to try and come up with optimal solutions for the conservation and restoration completed in 2014.

Key Words: Hapsburg sovereign; Maria Theresa; Martin van Meytens; Mayerwieser; oil on canvas; earlier restoration; probing; restoration; conservation. 